\title{
Bridging Governance Gap with Political CSR
}

\section{Adelopo, I.}

Associate Professor, Bristol Business School, University of the West of England, Bristol, United Kingdom.

Email: ismailadelopo@yahoo.com

Phone: +447828249752, +44(0)1173308109

\section{Yekini, $\mathrm{K}$.}

Senior Lecturer, Accounting \& Finance, Leicester Business School, De Montfort University, The Gateway, Leicester, LE1 9BH, United Kingdom.

Email: kyekini@dmu.ac.uk

Phone: +44 (0) 1162078783

\section{Raimi, L.}

Senior Lecturer, Centre for Entrepreneurship Development (CED), Yaba College of Technology, Lagos, Nigeria \& Doctoral Fellow, Leicester Business School, De Montfort University, The Gateway, Leicester, LE1 9BH, United Kingdom.

Email: Lukman.raimi@myemail.dmu.ac.uk, luq_man2001@yahoo.com

Phone: +2348023462555 


\begin{abstract}
Corporate social responsibility (CSR) has attracted varied applications in management. This chapter contribution provides evidence of a political CSR where multinational corporations (MNCs) are complementing government's role in bridging governance gap. The governance gap thesis and political costs hypothesis provide grounding for the discussions in this paper. Data from case studies across the Middle-Eastern countries were critically analysed and justify the political and developmental undercurrents of CSR initiatives. The key argument is that governance is crucial for development, and where there is a governance gap, it is in the interest of corporations to bridge the gap with their CSR initiatives to stimulate development. Pressure groups and civil society organisations in developing countries could leverage on the political dimension of CSR to lobby corporations to intervene in socio-economic issues especially poverty alleviation through entrepreneurship development in their operating environment for mutual benefits.
\end{abstract}

Keywords: Developing Countries, Governance Gap, Political Corporate Social Responsibility 


\section{I: Introduction}

Corporate social responsibility (CSR), although an old concept, has taken a new dimension in recent times (Broomhill, 2007). It has emerged as a topical issue in management and international business literature (van Tulder and van der Zwart, 2006). In the globalised world, the term CSR attracts limitless definitions and synonyms namely: corporate conscience, corporate citizenship, social performance, sustainable responsible business, responsible business (Wood, 1991; Amaeshi et al, 2006) and triple bottom lines (Haskins, 2009). The domain of CSR encompasses social philanthropy (Carroll, 1999; Smith, 2011) and extends to curtailing impact of industrial effluents on the environment, sustainability, biodiversity, trust, and legitimacy of corporate behaviours (Crowther and Rayman-Bacchus, 2004; Tombs, 2005; Hart, 2012). CSR has also been viewed as corporate altruism (Lantos, 2001) and social responsible investment (George, Kuye and Onokala, 2012; Scholtens, 2014). With regards to compliance with international standards and best practice, Valmohammadi (2011) includes within the scope of CSR seven core elements of ISO 26000 standards, viz: organizational governance, human rights, labour practices, the environment, fair operating practices, consumer issues, community involvement and development.

Viewing CSR as an umbrella term opens a leeway for its innovative reinvention and application. In developing nations with infrastructural deficit, there is upsurge in corporations' involvements in the wellbeing of their host communities; the MNCs flag nuances such as community engagement (Yekini, 2012), social entrepreneurship and corporate social entrepreneurship (Covin and Miles, 1999; Austin and Reficco, 2009), corporate citizens (Amaeshi et al, 2006) or responsible investors/responsible investment (Scholtens, 2014) as evidence of their commitments to business-society relationships. Notable corporations like General Electric, IBM, Google, eBay, Johnson \& Johnson, Grameen Bank \& Grameen Foundation; KaBOOM; DonorsChoose, Intel, Nestlé, Unilever and Wal-Mart are using CSR as worthwhile tool for sustainable development of their host nations without losing their economic objective (Kerr, 2007; Haskins, 2009; Porter and Kramer, 2011; Akhuemonkhan, Raimi and Ogunjirin, 2012).

In pursuit of the intent, the reviewed literature focused more on the relationship between CSR and financial performance metrics like improved profitability, enhanced customer patronage, positive stock market rating, reputation building, ease of access to bank loans and other economic measurements of performance (Waddock and Graves, 1997; Walsh, Weber and Margolis, 2003; Sweeney, 2009). However, very modest attention is given to reinvention of CSR as a developmental and political tools to complement role of the state, and especially in developing countries, where poverty, lack of inclusiveness, corruption, crime, unemployment, bad governance and underdevelopment have become endemic (Akhuemonkhan, Raimi and Ogunjirin, 2012; Amaeshi et al, 2006; Frynas, 2005; Idemudia, 2011; Sharp, 2006; Wold Bank, 2003).

Pioneering studies on political CSR is traced to Scherer and Palazzo (2007); Scherer and Palazzo (2008); Baumann and Scherer (2010); Scherer and Palazzo (2011); Matten (2003) and Matten and Crane (2005). In a unique style, Matten (2003) describes newly emerging political role of corporations as symbolic politics (SP) because several corporations are political actors in the design and implementation of environmental regulation in their host communities/countries after globalisation has ascribed increasing responsibility to them. The implication of this development 
is the erosion of traditional roles and powers of national governments. Similarly, Matten and Crane (2005) alluded to the political role of corporations within the corporate citizenship discourse in another novel work.

This chapter contribution, therefore, fills the knowledge gap on political CSR and developmental-oriented CSR by reviewing pioneering works on the subject matter with evidence from selected corporations which have deployed their CSR investments for political developmental purposes. We present the rest of the chapter in four parts. Part II is devoted to a review of the conceptual literature and the different dimensions of political CSR. Part III provides theoretical groundings for the paper relying on governance gap thesis and political cost theory. Part IV presents the methods and analysis. Part V is the conclusion and recommendations segment of the research.

\section{II: Literature review Conceptual Issues}

Political CSR is defined by leading proponents as a theory and practice whereby corporations and civil society groups take on the roles traditionally assigned, ascribed and assumed by the governments in a democratic milieu (Scherer and Palazzo; 2008). Edward and Willmott (2008) explained that a political CSR perspective merely extended the understanding of role of corporations in the political processes of their host countries beyond the conventional explanation of corporate citizenship. According to Scherer and Palazzo (2007), the conventional understanding of CSR in business-society research could be classified into two schools, namely: positivist and post-positivist CSR. The positivist perspective of CSR is considered weak because it views CSR in theory and practice as an instrumental and normative concept, while the postpositivist perspective of CSR suffered the same criticism because of its relativism, foundationalism, and utopianism. The political CSR as new theorizing emerged to strengthen existing perspectives of CSR with regards to interventionist roles of corporations in the contemporary times (Scherer and Palazzo, 2007, 2008, 2011). In other words, the "insertion of 'political' into corporate social responsibility (CSR) is intended to replace an implicit compliance with assumed societal norms and expectations with an explicit participation in public processes of political will formation” (Edward and Willmott, 2008:771).

Political CSR emerged for several reasons - (a) globalisation pressure, (b) need for inclusiveness in governance, (c) socio-political risk management and (d) pervasive infrastructural deficits in developing nations. Globalisation is an unstoppable wave; that necessitated a political CSR in a changing world and its influence has used by corporation beyond the domain of business for "transformation of private attitudes, morals, practices, and institutions" in regions where MNCs have influence and control (Donaldson, 2010:728). The globalisation wave aided MNCs like KFC, McDonalds, Coca-Cola, Johnson \& Johnson, Nike, Sony, Unilever and Nestle to establish their presence and influence across the globe. In the MENA, the same wave spurred corporations like Western Zagros Limited, HSBC, Al Muhaidib Group and SEDCO Holding to refocus their CSR programmes on economic growth and redevelopment of the local communities (Booz and Company, 2013). 
Secondly, the need for inclusiveness in governance became expedient because of the changing role of governance which allows for role-sharing among three key actors (the state, civil society and corporation) in the face of increasing challenges of government and dwindling resources (Akhuemonkhan et al, 2012). With regards to politics of inclusiveness, the private sector actors argued that politics or governance is a cumulative process that involves consultations, disagreement and consensus building among state actors and non-state actors; it is not an exclusive activity reserve for, or confined to agencies or institutions of the states (Scherer and Palazzo, 2008; Scherer and Palazzo, 2011). Within the political CSR framework, the three actors that emerged have complementary roles in governance (see Figure 1 below). The role of the state is essentially to provide an enabling environment for capitalism (Porter and Kramer, 2011). The role of the civil society group is to serve as watch dog/underdog for mounting pressures on corporations. The civil society group include private, independent organizations, including NGOs, social movement organizations, institutional investors, and the press (Campbell, 2007:958). The role of corporations is to complement government by contributing to economic growth and development in different ways (Gond and Matten, 2007; Akhuemonkhan et al., 2012).

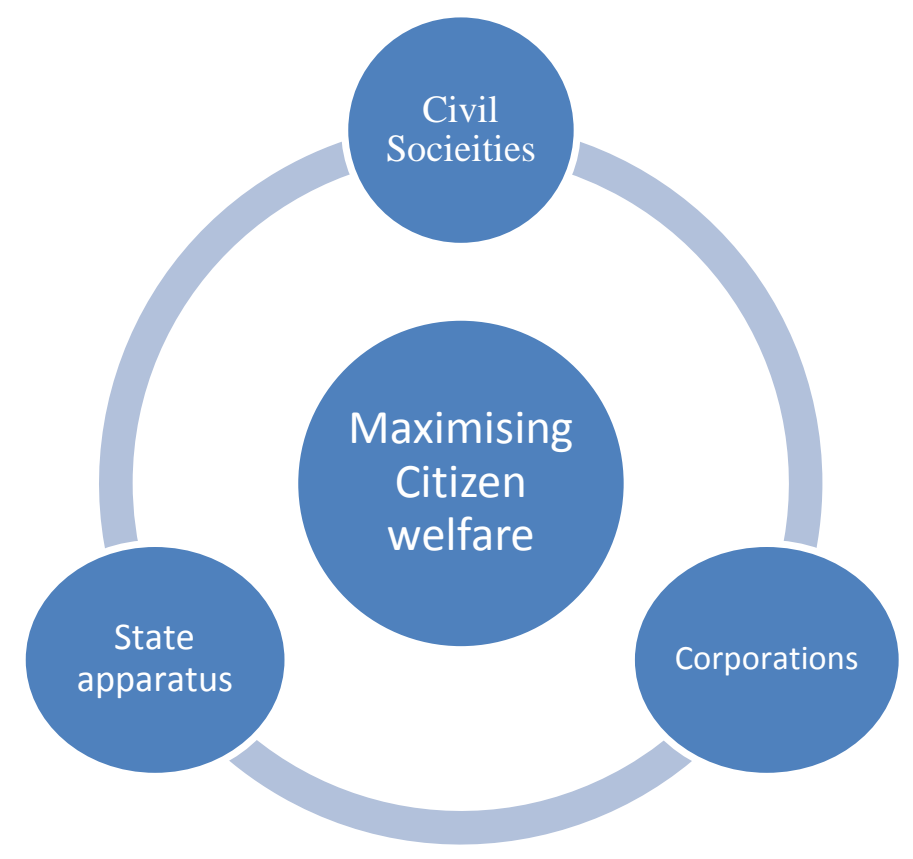

Figure 1: The three key actors

Thirdly, a political CSR emerged because of the need to mitigate the social and political risk posed by corporations' industrial activities in some host communities (Kytle and Ruggie, 2005; Nwadialor and Igwe, 2013). Social involvement in such environment becomes political in order to reconcile and demonstrate empathetic concerns for their wellbeing as well as curbing social and environmental degradation arising from the corporation's industrial activities (Raimi and Adeleke, 2010; George, Kuye and Onakala, 2012). For instance, there are unending oil spillages, pollutions, chemical diffusion and emissions of carbon monoxides as well as abuse of the ecosystem linked to MNCs like Shell, Chevron and Exxon Mobil (Friends of the Earth, 2004). A 
political CSR is therefore favoured because of the prospect of creating a Business of Peace (BOP) in hostile communities (Nelson, 2000). Put differently, it represents a compensatory mode of CSR (Mordi et al, 2012).

Table 1: Characteristics of the instrumental and the new political approach to CSR

\begin{tabular}{|c|c|c|}
\hline Characteristics & Instrumental CSR & Political CSR \\
\hline \multicolumn{3}{|l|}{ Governance model } \\
\hline - Main political actor & State & $\begin{array}{l}\text { State, civil society, and } \\
\text { corporations }\end{array}$ \\
\hline - Locus of governance & National governance & Global and multilevel governance \\
\hline - Mode of governance & Hierarchy & Heterarchy \\
\hline - Role of economic rationality & $\begin{array}{l}\text { Dominance of economic } \\
\text { rationality }\end{array}$ & $\begin{array}{l}\text { Domestication of economic } \\
\text { rationality }\end{array}$ \\
\hline $\begin{array}{l}\text { - Separation of political and economic } \\
\text { spheres }\end{array}$ & High & Low \\
\hline \multicolumn{3}{|l|}{ Role of law } \\
\hline - Mode of regulation & Governmental regulation & Self-regulation \\
\hline - Dominant rules & Formal rules and 'hard law' & Informal rules and 'soft law' \\
\hline - Level of obligation & High (enforcement) & Low (voluntary action) \\
\hline - Precision of rules & High & Low \\
\hline - Delegation to third parties & Seldom & Often \\
\hline \multicolumn{3}{|l|}{ Responsibility } \\
\hline - Direction & Retrospective (guilt) & Prospective (solution) \\
\hline - Reason for critique & Direct action & Social connectedness (complicity) \\
\hline - Sphere of influence & Narrow/local & Broad/global \\
\hline \multicolumn{3}{|l|}{ Legitimacy } \\
\hline - Pragmatic legitimacy & $\begin{array}{l}\text { High (legitimacy of capitalist } \\
\text { institutions via contribution to } \\
\text { public good) }\end{array}$ & $\begin{array}{l}\text { Medium-low (capitalist institutions } \\
\text { under pressure, market failure and } \\
\text { state failure) }\end{array}$ \\
\hline - Cognitive legitimacy & $\begin{array}{l}\text { High (coherent set of morals that } \\
\text { are taken for granted) }\end{array}$ & $\begin{array}{l}\text { Medium-low (individualism, } \\
\text { pluralism of morals) }\end{array}$ \\
\hline - Moral legitimacy & Low & $\begin{array}{l}\text { High-low (depending on level of } \\
\text { discursive engagement) }\end{array}$ \\
\hline - Mode of corporate engagement & Reactive (response to pressure) & $\begin{array}{l}\text { Proactive (engagement in } \\
\text { democratic politics) }\end{array}$ \\
\hline \multicolumn{3}{|l|}{ Democracy } \\
\hline - Model of democracy & Liberal democracy & Deliberative democracy \\
\hline - Concept of politics & Power politics & Discursive politics \\
\hline $\begin{array}{l}\text { - Democratic control and legitimacy of } \\
\text { corporations }\end{array}$ & $\begin{array}{l}\text { Derived from political system, } \\
\text { corporations are de-politicized }\end{array}$ & $\begin{array}{l}\text { Corporate activities subject to } \\
\text { democratic control }\end{array}$ \\
\hline - Mode of corporate governance & Shareholder oriented & Democratic corporate governance \\
\hline
\end{tabular}

Source: Scherer \& Palazzo (2011).

The fourth reason that brought political CSR to limelight is the need to bridge infrastructural deficits in host communities with failed public governance. According to Boyle and Boguslaw (2007), corporations have become active in tackling poverty issues in their operational domains through CSR involvements. Also, Natufe (2011) confirms that Adidas, Nike, IBM, BP and several MNCs have passionately adopted CSR as a tool for impacting on the business environment where they all operate. Furthermore, some studies provide justification for political CSR as a tool for tackling problems of poverty, unemployment, crime, conflict and 
infrastructural neglects in Nigeria and Tanzania (Ufadhili, Yambayamba and Fox, 2005; Raimi and Adeleke, 2010).

Related to the instances listed above, Charitoudi, Giannarakis and Lazarides (2011) note that corporations have proactively used CSR as tool for national economic recovery in the period of financial crisis, by catering for welfare needs of the poor members of the society. In essence, a political CSR represents a tool for bringing the suffering citizens out of devastating "bottom of the pyramid" (Boyle and Boguslaw, 2007:103). On the strength of the viewpoints above, the distinctions between the conventional CSR (which is instrumental) and the political CSR are as depicted in Table 1 above.

The political CSR that underpins this conceptual paper is CSR-Entrepreneurship synergy, a form of developmental CSR. This type of CSR finds relevance in developing countries where small and medium enterprises (SMEs) are hindered by governance constraints especially infrastructural deficiencies and unfriendly business environment (Newberry, 2006; Oyelola, et al., 2013). The afore-mentioned governance constraints which is global, have engendered weak SMEs which cannot create jobs, add value to national GDPs nor able to improve the quality of lives of their citizens.

\section{Approaches for Reinventing CSR as a political tool}

Corporate social involvement, historically, has social and political undercurrents. As a social concept, CSR at a formative stage was used as palliatives for supporting the society. At present the role of CSR has expanded as corporations used their CSR as a political tool to further imperialistic and exploitative goals in developing nations. In other words, corporations, especially MNC, are empowered to pursue political agenda, while at the same time doing business in developing nations. CSR is a political weapon deployed by MNCs to cushion the ripple effect of market failures and other negative externalities they engender while doing businesses. Contrary to the explanation above, Pratap (2011) argues that CSR is a farce and a political tool of neoliberals designed as "relief measures [intentionally to save]... the reputation, credibility and acceptability of the market god, corporate priests and the whole neoliberal religion. It is in this context that the role of corporate social responsibility (CSR) has been created. It has been propagated that the 'externalities', the term neoliberals give to poverty, unemployment and environmental disasters, that result from 'market failures', should be taken care of by voluntary corporate initiatives” (p.1)

From the foregoing discussion, the application of CSR by corporations have taken four (4) motives (instrumental, contingent, legitimacy and political). The scope of involvement in socioeconomic wellness of the society by corporations determines which motive to be given preference. With regards to the practical application of a political CSR, Scherer and Palazzo (2011:918) contend that "corporations thereby become politicized in two ways: they operate with an enlarged understanding of responsibility; and help to solve political problems in cooperation with state actors and civil society actors.”

Figure 2 below provides a visual explanation of the various motives for corporate social involvement by corporations. Whilst the first three are well documented in the literature, political motive for CSR is emerging. There are several cases of enlarged politically-motivated interventions across the globe. For instance, a political CSR has often been used for lobbying and 
reconciling "conflicts (obvious or perceived) between public and private interests" in hostile communities (Fooks, Gilmore, Collin, Holden and Lee, 2013:283). In the Niger-Delta region in Nigeria, a replica of CSR as a conflict resolution tool is the partnership between Shell Petroleum Development Company (SPDC) and government-owned Niger Delta Development Commission (NDDC) aimed at building infrastructural facilities for the host communities, as well as empowering victims of environmental degradation caused by SPDC (Ite, 2005; Ite, 2007). Another instance is the British-American Tobacco (BAT), which utilised its CSR programmes as lobby for neutralising the negative impact of its products and gaining political support thereby averting harsh tobacco regulation \& control (Fooks et al., 2013). Besides, under the guise of political CSR, several MNCs provide supports through exports of military hardware to oppressive governments and as well give bribes to politicians in developing nations (Leigh and Evans 2009; Fooks et al., 2013). The next section looks at the theoretical foundation of a political CSR.

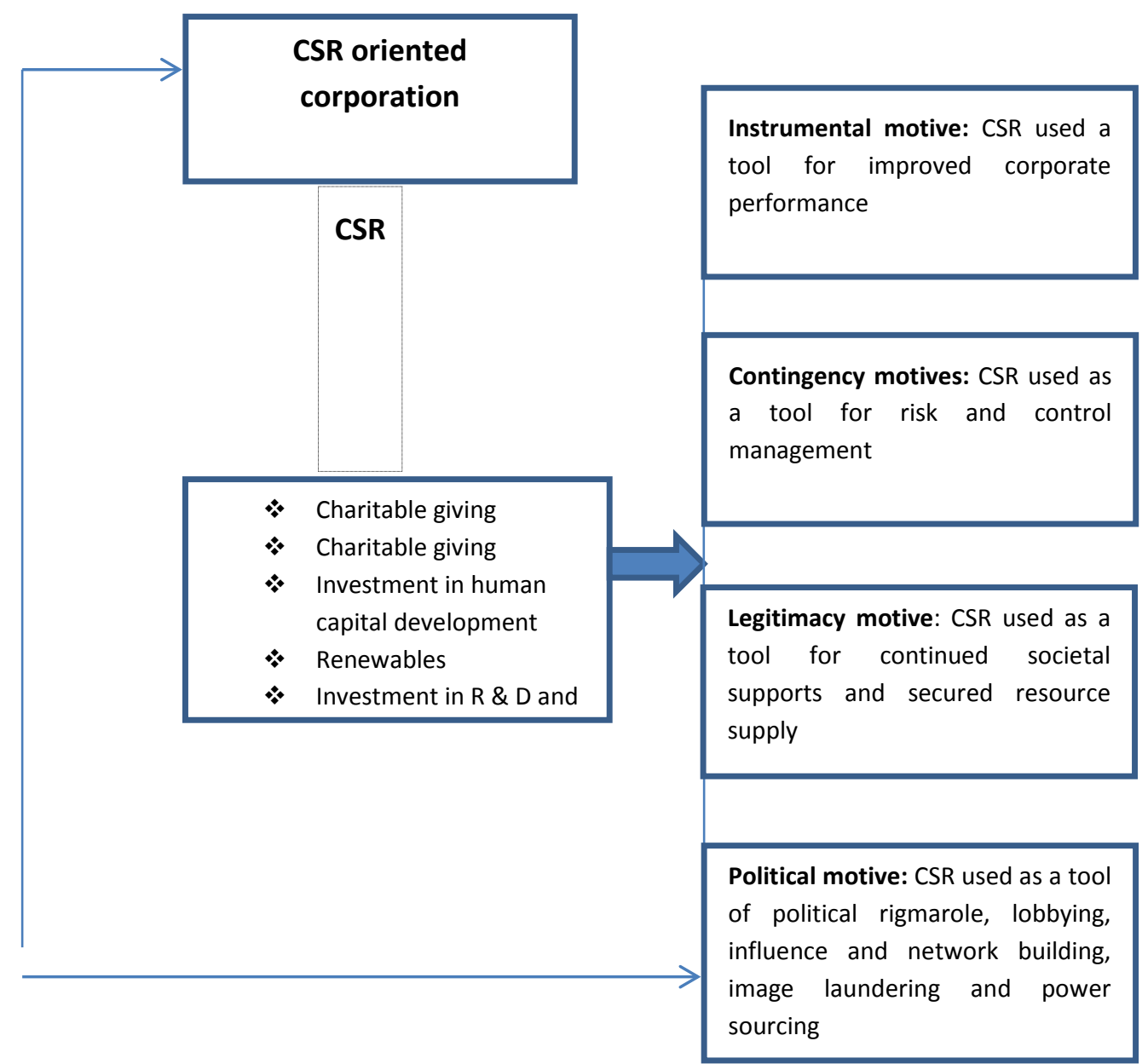

Figure 2: Motives for CSR (Adelopo, Yekini and Raimi, 2015) 


\section{III: Theoretical underpinning}

\section{Theoretical foundation}

Scherer and Palazzo (2007) hinged the political CSR on Jürgen Habermas's theory of democracy. The theory simply explains the emerging political roles of multinational corporations in their host countries in conjunction with two other players - governments and civil society groups. Habermas's theory of democracy is a new thinking and conception called deliberative democracy which advocates a hybrid democracy from two dominant political traditions, namely: (a) the public autonomy of republican political theory which emphasises the general will and popular sovereignty and (b) the private autonomy of liberal political theory which gives prominence to private interests and individual freedoms. The Habermas's deliberative model incorporates and integrates two political theories (republican and liberal political theories) to form a distinct political thought (Lubenow, 2012).

Within the present discourse, the two theories that provide further explanations for the political roles of corporations in the Habermas deliberative democracy are: (a) Governance Gap Thesis and (b) Political Cost Hypothesis. The two theories reinforce the Habermas's theory of democracy in the sense that they explain the rationale for the political roles of corporation in modern governance. The term governance has attracted varied definitions in the literature across multidisciplinary fields in the present millennium (Coyle, 2003; Blatter, 2012; Center for International Private Enterprise and Global Integrity, 2012). The World Bank (2003) admits that governance is a complex concept that lack distinct definition and measurement. In other words, governance touches how the affairs of politics are run and how the wellbeing of the society is overseen by managers.

Besides, Vrajlal and Kandarp (2010) define governance as an organised system employed by the private-sector, public-sector and not-for-profit sector for managing the affairs of their organisations. Governance (irrespective of levels) covers issues relating to organisational objectives, power-sharing, obligations as well as challenges of actors. Governance in practice could be dichotomised as depicted in Figure 3 below into good governance and bad governance (Young, 1999; Rizk, 2012). Good governance allows for efficient markets and provides effective government service delivery for the citizens. Government within a good governance system creates a public sector that is responsive and accountable as opposed to bad governance which creates a predatory and corrupt public sector (Center for International Private Enterprise and Global Integrity, 2012).
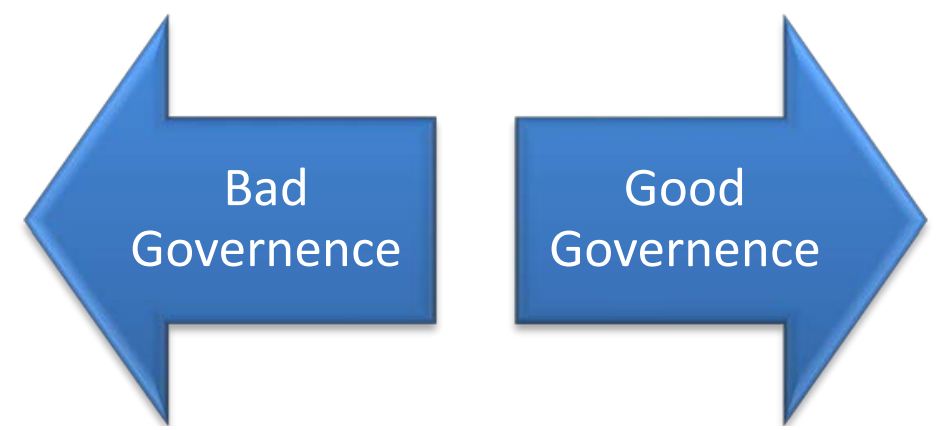

Figure 3: Divergence between Good and Bad Governance 
However, the crisis of ineffective service delivery to the citizens as a result of market failure and other factors is what theorists have described as Governance Gap (Dartey-Baah, and AmponsahTawiah, 2011; Blatter, 2012). The term 'governance gap' refers to a lack of integration in government's planning processes and a failure of public authorities to meet the expectations of the citizens in terms of provision of public goods. Similarly, it entails the inability of government at all levels to effectively communicate and deliver services to the public (Bates, 2011). With regards to Middle-East and North Africa (MENA), the World Bank (2003) report observed worsening performance linked to two dimensions of governance gap, namely: (a) poor quality of administration in the public sector and (b) weak public accountability. Both dimensions indicate that MENA has low tolerance for "the efficiency of the bureaucracy, the rule of law, the protection of property rights, the level of corruption, the quality of regulations, and the mechanisms of internal accountability... [as well as poor attitudes to] openness of political institutions and participation, respect of civil liberties, transparency of government, and freedom of the press” (World Bank, 2003:6-7).

To close the governance gap in MENA and other parts of Asian continent, and to allow for effective service delivery of quality public goods, there is need for collaboration and responsibility-sharing among governments, private sector, and civil society (Center for International Private Enterprise and Global Integrity, 2012). The collaboration by MNCs for role-sharing is necessary to complement government effort at improving wellbeing of the people (Visser, 2008). The governance gap thesis is applicable to all part of the globe where there is "Widespread poverty, corruption, inadequate resources, poorly trained labour supplies, wars and other forms of civil strife such as ethnic cleansing, pandemic diseases such as HIV/AIDS and malaria, tribal tensions, and ruinous economic policies have led to problems of such scope and dimension that it is only governments, African and international, that can mobilize the necessary capital to begin to make headway on these enormous issues” (Roy, 2010:49).

The solution to these ills caused by governance gap is for government to involve the privatesector corporations because they "have a creative role in defining possibly new ways of addressing these problems"(p.50). To forestall endemic poverty, the corporate businesses and multinationals need to appreciate the bitter truth that "poverty is a drain on resources that affects the business sector" once it is not tackled through intervention tool like the CSR (Boyle and Boguslaw, 2007). The next section discusses political cost theory.

Political cost theory provides explanation on why corporations wilfully bear certain social costs in their quest for economic survival through social disclosures and other income-reducing accounting methods designed to protect managerial interests (Watts and Zimmerman, 1990). The theory (otherwise called political cost hypothesis or positive accounting cost) explains that social costs are borne by flourishing corporations in order to response to pressures from politicians and civil society groups on social disclosures or social responsibility programmes (Milne, 2001). Another viewpoint argued that corporations incur huge costs in the political process of their communities to forestall the impact of external pressure on their operations (Watts and Zimmerman, 1978).

Political costs refer to social costs required by corporations for continuing operations and businesses in line with regulatory requirements prevailing in a particular environment 
(Emadzadeh et al., 2012). The political costs often incurred by corporations take the forms of environmental rehabilitation costs, financial support for ruling or preferred political parties, sports sponsorship, costs on seminar/capacity-building workshops, Insurance premiums, donations to party during elections, monetary \& non-monetary gifts and donations with political undertones (Tehrani, et al., 2009) as well as lobbying costs, cost of securing government contract and cost of avoiding government punitive regulations (Watts and Zimmerman, 1990; Emadzadeh, et al., 2012).

The Middle-East and North Africa (MENA) are behind several other nations on governance index; they have weak public sector because of poor openness, lack of transparency, weak reward system, dysfunctional institutional structures, widespread political corruption, poor policy implementation and inappropriateness of the policies/programmes (World Bank, 2003). For these nations to grow and catch up with their developed counterparts, there is the urgent need for a paradigm shift from cosmetic/palliative CSR to a viable political CSR that would help tackle hydra-headed poverty, unemployment, illiteracy, chronic diseases, maternal mortality, infant mortality, conflict, terrorism/insurgency in the developing nations, while at the same time promote growth of SMEs, wealth creation, enhance value reorientation, preserve the ecosystem from abuse and in the final analysis achieve sustainable economic development (Sagnia, 2005; Kauffmann, 2006; Akhuemonkhan et al, 2012).

Besides, the proponents of political cost hypothesis stated that the larger the corporation and its scope of operation, the large would be the spending on political costs (Watts and Zimmerman, 1978; Gray, Kouhy and Lavers., 1995; Milne, 2001). An attempt to investigate the applicability of the theory in Tehran using econometric analysis revealed that "there is a correlation between political costs and company's size. It means that by increasing company's size the political costs increase too and by decreasing companies' size their political costs decrease too" (Tehrani et al, 2009:339). In theory and practice, it could be concluded that political cost is just management behaviour to project corporation as socially responsible by defraying their profit through incomereducing social involvements (Emadzadeh, et al., 2012).

\section{Criticisms against Political CSR}

The use of CSR for politically-motivated social involvements within a capitalist free market system attracts criticisms. According to Brønn and Vrioni (2001), the debates on CSR have been confined to the domains of the free market proponents and socially-oriented proponents. The protagonists of a CSR with political colouration believe that emerging social problems like poverty, recession, environmental degradation and unemployment aggravated by the states 'inability to cater for critical welfare needs of the citizens provide justification for a political CSR (Charitoudi, et al., 2011; Porter and Kramer, 2011; Tausif, 2012). From conflict mitigation perspective, a political CSR is believed could complement government's efforts in boosting human capital development thereby helping to stem the tide of conflict and youth restiveness in the Middle-East and Asian continent. The UNESCO-UNEVOC (2012) lends credence to the statement above in its report that developing human capital has great prospect for tackling poverty, enhancing employability through skills acquisition and boosting sustainable development in Asia especially Arab states (MENA), where youth restiveness has resulted in violent protests and endemic demonstrations styled Arab Spring, Raimi and Akhuemonkhan (2013:131) notes that the Asia and Pacific region, "TVET has become a tool for enhancing social 
protection for the excluded/disadvantaged members of the society as well as a catalyst for economic development"

The antagonists argue that in a genuine capitalist economy, the primary responsibility of corporations is profit maximisation and that imperfection in the market economy and social problems are weak defence for corporate social involvements (Kakabadse et al., 2005). Secondly, social involvement is flawed from governance and legal viewpoints because involvement by managers of violates the terms of their engagements under the agency theory of corporate governance because participation is a violation of legitimate claims of shareholders to return on investment. In other words, all forms of CSR are conceptually and practically incoherent with business thinking within the capitalist domain, because social welfare services are counterproductive to owner’ human rights (Sternberg, 2009).

\section{IV: Methods and analysis}

The qualitative research method was adopted in this chapter contribution because of its exploratory nature, while relying on documentary sources for data collection. In the quest to get relevant cases to justify a political CSR, a search on google scholar for academic publications provided 25 citations on political roles of corporations in different parts of the world. The generated publications were systematically previewed to elicit relevant cases on political CSR with developmental undercurrents in the Middle-East and North Africa (MENA) and Asia. At the end, a sample of ten (10 cases provided evidences of political CSR activities in the MENA and Asia. The 10 cases were subjected to discourse analysis on the basis of which the CSR programmes in the region were described as political and developmental

\section{Evidence of Political CSR Initiatives}

At the end of the systematic preveiw of 25 academic publications, a sample of 10 relevent cases that provide evidences of political CSR activities in the MENA and Asia are as highlighted in Table 1 below.

\section{Reflection on Development-Oriented CSR}

CSR initiatives become political when corporations take over the role of government or complement efforts of government (Matten, 2003; Scherer and Palazzo, 20008; Scherer and Palazzo, 2011), while developmental side of CSR addresses national issues like poverty, unemployment, diseases, infrastructural needs (Frynas, 2005; Frynas, 2008; Idemudia, 2010; Sharp, 2006). The ten (10) cases presented above qualify as political and developmental CSR. Each of the cases represents a unique example of the interaction between corporations and the state in solving what would have been purely state responsibility. In our view, the corporate involvements are beyond what some may simply see as philanthropic initiatives. For example in case, 1 Aramex and Injaz corporations took over governmental role of unemployment reduction and attendant consequences like poverty, youth restiveness and hopelessness. This form of CSR initiative is developmental because it is channelled towards entrepreneurship development. The MENA countries have one of the most youthful population with about $65 \%$ of the population aged under 25. This represent close to 300 million people. This is in a region where youth unemployment stood at 25\% far above the global average of $14 \%$. 
Table 1: Political CSR Initiatives in Middle East and North Africa (MENA) and Asia

\begin{tabular}{|c|c|c|}
\hline SN & Description of Case of PCSR & Country \\
\hline 1. & $\begin{array}{l}\text { Case 1: Creating the Culture of Entrepreneurship by Aramex and Injaz corporations. } \\
\text { The CSR initiatives of Aramex and Injaz corporations were designed to solve rising youth } \\
\text { unemployment and constraints facing the SMEs in the Middle East and Southeast Asia. The } \\
\text { above-mentioned corporations initiated an entrepreneurship education programme (EEP) in } \\
2007 \text { to motivate youth to create jobs (Murphy, 2010). }\end{array}$ & $\begin{array}{l}\text { Middle East } \\
\text { and Southeast } \\
\text { Asia }\end{array}$ \\
\hline 2. & $\begin{array}{l}\text { Case 2: Building Skills and Capacity for Entrepreneurship by Chevron } \\
\text { Chevron established in Indonesia a CSR initiative tagged Chevron Pacific Indonesia (CPI) } \\
\text { to support small and micro enterprises (SMEs). The scheme trained over 4,000 small local } \\
\text { businesses and cooperatives. The model provided financial support to the tune of } \$ 1.3 \\
\text { million in } 2001 \text { to small businesses and more than } \$ 114 \text { million in } 2009 \text { (Murphy, 2010). }\end{array}$ & Indonesia \\
\hline 3. & $\begin{array}{l}\text { Case 3: Partner in community development by Zain Bahrain } \\
\text { ZAIN Bahrain provides community support services directed at Environmental Issues, } \\
\text { Education, Youth Engagements, Women empowerment Empowering and children-oriented } \\
\text { philanthropy and Research \& Development on Technological Progress. Internship program } \\
\text { called GenNext was developed as Future University Network provides students with a hands-on } \\
\text { experience of work in the company (Zain Bahrain, 2013). }\end{array}$ & Bahrain \\
\hline 4. & $\begin{array}{l}\text { Case 4: Technical and Vocational Development in Host Community by Chevron } \\
\text { Chevron established Chevron Aceh Recovery Initiative (CARI) to empower the local } \\
\text { community through social investments in vocational and technical skill-acquisition } \\
\text { programmes in order to improve job prospects and launching of new enterprises. Chevron's } \\
\text { project intends to empower } 1,200 \text { SMEs, which would create additional } 6,000 \text { jobs for } \\
\text { Indonesians (Murphy, 2010). }\end{array}$ & Indonesia \\
\hline 5. & $\begin{array}{l}\text { Case 5: Embedding Sustainable Development in Local Areas by WesternZagros } \\
\text { WesternZagros Limited, a Canadian owned company integrates the wellbeing of the } \\
\text { local communities into its business operations for long-term benefits. Its CSR programs } \\
\text { cover community redevelopment, employment for locals, educational support, health } \\
\text { and water supply. }\end{array}$ & Iraq \\
\hline 6. & $\begin{array}{l}\text { Case 6: Entrepreneurship and Small Business Promotion by CISCO } \\
\text { As part of CISCO's support for the host community, it initiated an entrepreneurship } \\
\text { schemes aimed at inculcating "skills necessary to turn a business dream into reality" } \\
\text { through global programs executed under Global Education Initiative, the Cisco Networking } \\
\text { Academy, and the Cisco Entrepreneurship Institute.” (Murphy, 2010:12). }\end{array}$ & $\begin{array}{l}\text { Egypt, } \\
\text { Lebanon, } \\
\text { Jordan, } \\
\text { S/Arabia, Qatar }\end{array}$ \\
\hline 7. & $\begin{array}{l}\text { Case 7: Building Skills and Capacity of Students by CISCO } \\
\text { For student empowerment, Cisco is funding education under public-private education } \\
\text { partnerships in Jordan, Egypt and Qatar. It also partnered with the United States } \\
\text { Department Middle East Initiative, to provide "internship opportunities for women from } \\
\text { Lebanon, Jordan and Saudi Arabia on entrepreneurship and business courses at Emory and } \\
\text { Duke Universities. Records indicated that Cisco "has nearly one million students in } 165 \\
\text { countries." (Murphy, 2010:12). }\end{array}$ & $\begin{array}{l}\text { Egypt, } \\
\text { Lebanon, } \\
\text { Jordan, Saudi } \\
\text { Arabia, Qatar }\end{array}$ \\
\hline 8. & $\begin{array}{l}\text { Case 8: Business Linkages by National Beverage Company Coca-Cola/Cappy } \\
\text { Coca-Cola/Cappy (National Beverage Company) utilised its CSR as support mechanism for } \\
\text { local entrepreneurs and SMEs in the Middle-East and West Bank The CSR initiative is an } \\
\text { inclusive business models created to help suppliers, distributors and retailers as well } \\
\text { strengthening the local business system to protect its own markets (Murphy (2010). }\end{array}$ & $\begin{array}{l}\text { Middle-East, } \\
\text { West Bank }\end{array}$ \\
\hline 9. & $\begin{array}{l}\text { Case 9: Business Linkages in Singapore, Wales, Ireland, Vietnam, Thailand } \\
\text { The CSR-oriented business linkages across the world provide logistic and financial support } \\
\text { to SMEs through the private sectors. Luetkenhors (2004) noted that the aim of the CSR- } \\
\text { oriented business linkage is to enhance the capabilities and performance of SMEs as } \\
\text { partners of MNCs. Selected CSR-oriented business linkage include: Singapore's Local } \\
\text { Industry Upgrading Programme, the Source Wales programme, Ireland's National Linkage }\end{array}$ & $\begin{array}{l}\text { Singapore, } \\
\text { Wales, Ireland, } \\
\text { Vietnam, } \\
\text { Thailand } \\
\text { Malaysia } \\
\text { China }\end{array}$ \\
\hline
\end{tabular}




\begin{tabular}{|l|l|l|}
\hline & $\begin{array}{l}\text { Programme and the programmes of Unilever in Vietnam, Toyota in Thailand, Intel in } \\
\text { Malaysia, Motorola in China et cetera. }\end{array}$ & \\
\hline 10. & $\begin{array}{l}\text { Case 10: CSR-Cluster Model in the Sialkot (India) and Jalandhar (Pakistan) } \\
\text { The Cluster model in India and Pakistan owned by Sialkot and Jalandhar respectively } \\
\text { attracted support from the Soccer Industry Council of America, the International Labour } \\
\text { Organization, the United Nations Children Fund, Labour Organisation (ILO), UNICEF, } \\
\text { Save the Children - UK and the Sialkot Chamber of Commerce and Industry for being } \\
\text { supportive of child/poor families in their host communities (UNIDO, 2009) }\end{array}$ & \\
\hline
\end{tabular}

Source: Author (2014)

One striking feature of this partnership is its long-term perspective which means that both parties can develop trust and closer working relationship in the understanding that durable developmental infrastructure are been built for the future.

Case 2 is a political CSR like the former because Chevron desires to fill governance gap and elicit legitimacy in its host country by building capacity of small local businesses and cooperatives in Indonesia through entrepreneurship training scheme and provision of financial support to the beneficiaries. Case 3 qualifies as a political CSR because Zain as one of the leading telecommunication corporations in Bahrain, focused community development especially on the delivery of public goods for the citizens. Zain's CSR initiative is developmental because the issues targeted are environmental issues, educational support, youth engagements, funding of research \& development, women empowerment and children-oriented support programs, which are aimed at stimulating sustainable growth and development in the host country.

Case 4 like others discussed above is political and developmental. Chevron as a notable MNC desires to establish its presence in Indonesia. The country has large market and economic potentials by virtue of its large population. The CSR initiative of Chevron is development because the issue focused is the development of technical and vocational education designed to enhance the skills of Indonesians thereby improving their job prospects and capacity to launch new enterprises. Case 5 is a political CSR initiative of Western Zagros Limited, a Canadian owned company in Iraq. Iraq being a turbulent region, the company initiated its CSR to complement the role of Iraqi government by providing public goods and welfare support services to the poor citizens. Secondly, intervention in welfare enhancement provides legitimacy for the corporation in the hostile Iraqi communities. Cases 6 and 7 have both political and developmental impacts. In a bid to elicit social license, empower women and stimulate small business development in Egypt, Lebanon, Jordan, S/Arabia and Qatar, CISCO a leading MNC initiated an entrepreneurship schemes aimed at building the entrepreneurship capacities of the youth for self-employment and self-reliant. It is hoped that businesses established by the youth and women would reduce unemployment, poverty rate, social exclusion and other social ills that are pervasive in the MENA. For women empowerment, CISCO provided internship opportunities for women from the above-mentioned countries on entrepreneurship and business courses at Emory and Duke Universities. Case 8 is political because National Beverage Company (Coca-Cola/Cappy) desires to entrenched it business influence in turbulent MiddleEast region of West Bank and Gaza in spite of the conflict in the region. National Beverage Company's initiatives are developmental because the citizens of the benefiting countries are being economically empowered through business support linkages as described above. Case 9 is a developmental CSR with political undercurrent. In Vietnam, Thailand, Malaysia and China, notable MNCs like Unilever, Toyota, Intel and Motorola respectively have developed CSR- 
oriented business linkages to provide logistic and financial support to SMEs to enhance their capabilities and performance as partners within the value chains. This CSR model is carefully designed to gain recognition from the governments of host countries and public legitimacy as corporate citizens. Finally, Case 10 is political because Sialkot and Jalandhar corporations through its CSR initiatives assisted the international community in embedding international protocols on child labour in India and Pakistan respectively. It is developmental because the victims of child labour were sent to schools with the expenses borne by the two corporations.

\section{V: Conclusion, Implication and Recommendations}

MNCs invoked a political CSR with developmental impact to elicit legitimacy and socio-

economic licenses from the social licensers (public, regulatory agencies and politicians). The practical implication of the paper is that in the MENA and Asia where there is governance gap, it is in the interest of MNCs to bridge the gap with CSR initiatives. However, involvement of MNCs in social issues should not encourage government to abdicate its core statutory responsibility of provision of public goods as well as effective service delivery. The conclusion from the paper is that developing nations could leverage on the political dimension of CSR, by demanding from corporations more involvement in community development for mutual benefits. Future studies could undertake an empirical investigation of a political CSR which policymakers could explore for practical application of a political CSR to solving problems of poverty, unemployment and conflicts in MENA and Asia. The principle of voluntarism that drives the conventional CSR should guide the embedment of a political CSR. In other words, a political CSR should strictly be pursed as a private-sector driven model because there is preference for private-sector led development initiatives. The role of the government with a political CSR mechanism should simply be limited to providing legitimacy and enablement for a smooth business-society relationship. Government could encourage participation not coercion of MNCs. Coercive CSR compliance would be akin to double taxation. Civil society groups should be vigilant with regards to political CSR that subverts democracy and national independence like the ploy of rouge corporations, which deployed CSR programmes as lobby for neutralising the negative impact of their products and gaining support from politicians. Finally, social ills such as worsening poverty, governance deficit improving, political corruption, poor labour standards, environmental degradation, surging violence, industrial pollution as well as chronic diseases are problems that MNCs could help tackle sustainably through genuine a political CSR. 


\section{REFERENCE}

Akhuemonkhan, I., Raimi, L., Ogunjirin, O. D. (2012) 'Corporate Social Responsibility and Entrepreneurship (CSRE): Antidotes to Poverty, Insecurity and Underdevelopment in Nigeria', paper delivered at international conference on Poverty, Insecurity and Development in Africa, Universiti de Lome, Republic of Togo, November 1-2.

Amaeshi, K. M., Adi, B. C., Ogbechie, C. and Amao, O. O. (2006) 'Corporate social responsibility in Nigeria: Western mimicry or indigenous influences?' Journal of Corporate Citizenship, 24: 83-99.

Austin, J. and Reficco, E. (2009) ‘Corporate Social Entrepreneurship’, Harvard Business School, Working Paper Number: 09-101: 1-8.

Bates, S. (2011) 'Bridging the Governance Gap: Strategies to Integrate Water and Land Use Planning', Center for Natural Resources and Environmental Policy, The University Of Montana. Policy Report No. 7.

Baumann, D. and Scherer, A. G. (2010) MNEs and the UN Global Compact: An Empirical Analysis of the Organizational Implementation of Corporate Citizenship. IOU Working Paper No. 114. Available: http://ssrn.com/abstract=1705532 (Accessed: 13 October, 2014).

Blatter, J. (2012) 'Forms of Political Governance - Theoretical Foundations and Ideal Types', Working Paper Series, Global Governance and Democracy, Universitat Luzern, Germany. http://www.unilu.ch/files/wp7_forms-of-political-governance.pdf (Accessed: 25 February, 2014).

Booz and Company (2013) 'The Rise of Corporate Social Responsibility - A Tool for Sustainable Development in the Middle East', Available: http://www.booz.com/media/file/BoozCo_The-Rise-of-Corporate-Social-Responsibility.pdf (Accessed: 6 March, 2014).

Boyle, M and Boguslaw, J (2007) 'Business, Poverty and Corporate Citizenship Naming the Issues and Framing Solutions. Journal of Corporate Citizenship’, Greenleaf Publishing, Summer: 101-120.

Brønn, P. S. and Vrioni, A. B (2001) 'Corporate Social Responsibility and Cause Related Marketing: an Overview’, International Journal of Advertising, Vol. 20(2): 207-222.

Broomhill, R. (2007) 'Corporate Social Responsibility: Key Issues and Debates’, Dunstan Paper No. 1, Don Dunstan Foundation, Available: http://firgoa.usc.es/drupal/files/Ray_Broomhill.pdf (Accessed: 26 February, 2014).

Campbell, J. L. (2007) 'Why would corporations behave in socially responsible ways? An institutional theory of corporate social responsibility', Academy of Management Review, 32, 946-967.

Carroll, A. (1999) 'Corporate Social Responsibility-Evolution of a Definitional Construct', Business \& Society, Sage Publications, Inc., 38(3), September, 268-295.

Center for International Private Enterprise and Global Integrity (2012) 'Improving Public Governance: Closing the Implementation Gap between Law and Practice’, 
Available:http://www.cipe.org/sites/default/files/publicationdocs/GI\%20CIPE_Implementation\%20Gap_for\%20web.pdf (Accessed: August 5, 2013).

Charitoudi, G., Giannarakis, G. and Lazarides, T. G. (2011) 'Corporate Social Responsibility Performance in Periods of Financial Crisis', European Journal of Scientific Research, EuroJournals Publishing, Inc., 63(3), pp. 447-455.

Coyle, D. (2003) Corporate governance, public governance and global governance: the common thread', Working Paper, Institute of Political and Economic Governance, University of Manchester, December.

Crowther, David and Rayman-Bacchus, L. (2004) Perspectives on corporate social responsibility', Ashgate Publishing, Ltd.

Covin, J. G., \& Miles, M. P. (1999) Corporate entrepreneurship and the pursuit of competitive advantage', Entrepreneurship Theory and Practice, Vol. 23 No.3: 47-63.

Dartey-Baah, K. and Amponsah-Tawiah, K. (2011) Exploring the limits of Western Corporate Social Responsibility Theories in Africa', International Journal of Business and Social Science, Vol. 2(18):126-137.

Donaldson, T. (2010) The Values Realignment in Modern Industrial Society'. Business Ethics Quarterly, Vol. 20(4):728-729.

Edward, P., and Willmott, H. (2008) Corporate citizenship: rise or demise of a myth?. Academy of Management Review, 33(3), 771-773.

Emadzadeh, M. K., Shahrestani, B. A., Safanoor, M. and Shahraki, K. (2012) The Survey of Relationship between Size of Firms and Political Costs', Interdisciplinary Journal of Contemporary Research in Business, Vol 3(10):355-356.

Frynas, J. G. (2005) 'The false developmental promise of Corporate Social Responsibility: evidence from multinational oil companies’, International Affairs, Vol 81(3): 581-598.

FrynaS, J. G. (2008) 'Corporate Social Responsibility and International Development: Critical Assessment’, Corporate Governance: An International Review, Vol. 16(4): 274-281.

Fooks, G., Gilmore, A. Collin, J., Holden, C. and Lee, K. (2013) 'The Limits of Corporate Social Responsibility: Techniques of Neutralization, Stakeholder Management and Political CSR. Journal of Business Ethics, Vol. 112 (2), pp 283-299.

Friends of the Earth (2004) 'Media Briefing on Gas Flaring in Nigeria', Underwood London, Available: http://www.foe.co.uk/sites/default/files/downloads/gasflaringinnigeria.pdf (Accessed: 3 March, 2014).

George, O.J, Kuye, O.L. and Onokala, U.C. (2012) 'Corporate Social responsibility (CSI) a catalyst to the Niger Delta Crisis: The case of Nigerian oil Multinational Companies Versus the militants of Niger Delta Region of Nigeria', Journal of management Research, Vol.4 (2), pp.111.

Gond, J. P., and Matten, D. (2007) 'Rethinking the Business-Society Interface: Beyond the Functionalist Trap’, ICCSR Research Paper series, No.47-2007. 
Gray. R., Kouhy. R. and Lavers.S. (1995) 'Corporate Social and Environmental Reporting: A Review of the Literature and a Longitudinal Study of UK Disclosure', Accounting, Auditing and Accountability, Vol. 8, No 2: 47-77.

Hart, R. (2012) 'Green Mining or Green Washing? Corporate Social Responsibility and the Mining Sector in Canada', Mining Watch Canada, Mine Alerte, September', Available: http://www.miningwatch.ca/sites/www.miningwatch.ca/files/Green\%20Mining\%20or\%20Green \%20Washing.pdf (Accessed: 24 February, 2014).

Haskins, C. (2009) 'Using the concept of sustainable development to encourage corporate responsibility in small enterprises', Working paper of Norwegian University of Science and Technology, Department of Industrial Economics and Technology Management Trondheim, Norway: 1-13.

Idemudia U. (2011) 'Corporate social responsibility and developing countries: Moving the critical CSR research agenda in Africa forward', Progress in Development Studies, 11(1), 1-18.

Ite, U. E. (2007) 'Partnering with the state for sustainable development: Shell's experience in the Niger Delta’, Nigeria. Sustainable Development, 15: 216-228.

Ite, U.E. (2005) 'Poverty reduction in resource-rich developing countries: what have multinational corporations got to do with it?', Journal of International Development, 17: 913929.

Kakabadse, N. K., Rozuel, C. and Lee-Davies, L. (2005) 'Corporate social responsibility and stakeholder approach: a conceptual review’, Int. J. Business Governance and Ethics, Vol. 1(4):277-302.

Kauffmann, C. (2005) 'Financing SMEs in Africa', Policy Insights No. 7, African Economic Outlook/African Development Bank/OECD Development Centre: 1-4.

Kerr, J. E. (2007) 'Sustainability Meets Profitability: The Convenient Truth of How the Business Judgment Rule Protects a Board's Decision to Engage in Social Entrepreneurship', Available: http://ssrn.com/abstract=1296270 or http://dx.doi.org/10.2139/ssrn.1296270 (Accessed: 5 March, 2014).

Kytle, B. and Ruggie, J. G. (2005) 'Corporate Social Responsibility as Risk Management - A model for Multinationals’, Corporate Social Responsibility Initiatives (CSRI) Working Paper No. 10. Cambridge M. A.: John F. Kennedy School of Government, Harvard University.

Leigh, D. and Evans, R. (2009) 'Fraud Office seeks BAE's prosecution over bribery', The Guardian, October 1.

Lubenow, J. A. (2012) Public Sphere and Deliberative Democracy in Jürgen Habermas: Theoretical Model and Critical Discourses. American Journal of Sociological Research, Vol. 2(4): 58-71

Matten, D. (2003) 'Symbolic politics in environmental regulation: corporate strategic responses', Business Strategy and the Environment,, Vol. 12(4): 215-226. 
Matten, D. and Crane, A. (2005) 'Corporate Citizenship: Toward An Extended Theoretical Conceptualization’, Academy of Management Review, Vol. 30(1): 166-179.

Milne, M. J. (2001) 'Positive Accounting Theory, Political Costs and Social Disclosure Analyses: A Critical Look', BAA Annual Conference at the University of Nottingham. Available:http://citeseerx.ist.psu.edu/viewdoc/download?doi=10.1.1.199.7620\&rep=rep1\&type= pdf (Accessed: August 25, 2013).

Mordi, C., Opeyemi, I. S., Tonbara, M. and Ojo, S. (2012) 'Corporate Social Responsibility and the Legal Regulation in Nigeria’, Economic Insights - Trends and Challenges, Vol. LXIV (1):1 8.

Murphy, S. (2010) 'Corporate Partnerships for Entrepreneurship: Building the Ecosystem in the Middle East and Southeast Asia', Corporate Social Responsibility Initiative Working Paper No. 62. Cambridge, MA: John F. Kennedy School of Government, Harvard University.

Natufe, O. I. (2011) 'Corporate Social Responsibility: Value and Strategic Intent', Social Responsibility Review, Number 2, pp. 14-25.

Nelson, J. (2000) 'The business of peace: Business as a partner in conflict resolution', London: Prince of Wales Business Leaders Forum.

Newberry, D. (2006) 'The role of small and medium-sized enterprises in the futures of emerging economies. World Resource Institute', Available: http://earthtrends.wri.org/features/view_feature.php?fid=69\&theme=5 (Accessed: 5 March, 2014).

Nwadialor, E. and Igwe, N. N. (2013) 'Adapting Corporate Social Responsibility Programs to Risk Management: A Model for Multinational Organizations in Nigeria’, European Journal of Business and Management, Vol.5, No.15, pp. 17-24.

Oyelola, O. T., Ajiboshin, I. O., Raimi, L., Raheem, S. and Igwe, .C. N. (2013) 'Entrepreneurship for Sustainable Economic Growth in Nigeria', Journal of Sustainable Development Studies, Vol. 2 (2), pp.197-215

Porter, M.E. and Kramer. M. R. (2011) 'Creating Shared Value: How to reinvent capitalismand unleash a wave of innovation and growth', Harvard Business Review (HBR), January/February, HBR:1-17.

Pratap, S. (2011) 'Corporate Social Responsibility and the Political Agenda of the Corporate', CSR Research Paper Series No 3, Asia Monitor Resource Centre, pp. 1-25. Available: http://www.amrc.org.hk/system/files/CSR\%20Research\%20Paper\%20Series\%20No\%203.pdf (Accessed: 28 February, 2014).

Raimi, L., Adeleke, I.A. (2010) 'Using Entrepreneurship Development and Corporate Social Responsibility as Strategies for Conflict Resolution in the Niger-Delta Region in Nigeria', Society of Petroleum Engineers - Nigeria Annual International Conference and Exhibition 2010, NAICE: 2837-846. 
Raimi and Akhuemonkhan, (2013) 'Has Technical Vocational Education and Training (TVET) impacted on Employability and National Development?' The Macrotheme Review 3(2):129146.

Rizk, R. (2012) 'Governance and Its Impact on Poverty Reduction: Is there a role for Knowledge Management?’ International Journal of Innovation and Knowledge Management in Middle East \& North Africa Vol. 1(1):81-104.

Roy, D. A. (2010) 'Trends in Global Corporate Social Responsibility Practices The Case of SubSaharan Africa', International Journal of Civil Society Law, Washington \& Lee School, 8(3) July: 48-64.

Sagnia, B. K. (2005) 'Strengthening local creative industries and developing cultural capacity for poverty alleviation', Sixth Annual Conference Background Document, International Network for Cultural Diversity, November 17-20, Dakar, Senegal.

Scherer, A. G., \& Palazzo, G. (2007). Toward a political conception of corporate responsibility: Business and society seen from a Habermasian perspective. Academy of Management Review, 32(4), 1096-1120.

Scherer, A.G. and G. Palazzo (2008) 'Globalization and Corporate Social Responsibility', in Oxford Handbook of Corporate Social Responsibility, A. Crane, et al., Editors. Oxford University Press: Oxford. p. 413-431.

Scherer, A.G. and Palazzo, G. (2011) 'The New Political Role of Business in a Globalized World: A Review of a New Perspective on CSR and its Implications for the Firm, Governance, and Democracy’, Journal of Management Studies. Vol. 48(4): 899-931.

Scholtens, B. (2014) 'Indicators of responsible investing Ecological Indicators', Vol. 36:382385.

Shamir, R. (2005) 'Corporate social responsibility: a case of hegemony and counter-hegemony', in Santos, B.S. and Rodriguez-Garavito, C.A. (Eds.), Law and Globalization from Below: 92117. Cambridge: Cambridge University Press.

Sharp, J., (2006) 'Corporate social responsibility and development: an anthropological perspective. Development Southern Africa’, Vol. 23 (2):213-222.

Smith, M. K. and Doyle M. (2002) 'Globalization' the encyclopedia of informal education, www.infed.org/biblio/globalization.htm (Accessed: 4 March, 2014).

Smith, R. E. (2011) 'Defining Corporate Social Responsibility: A Systems Approach For Socially Responsible Capitalism’ Master of Philosophy Dissertation (Unpublished), University of Pennsylvania, Philadelphia, Pennsylvania Available: http://repository.upenn.edu/cgi/viewcontent.cgi?article=1009\&context=od_theses_mp

Sternberg, E. (2009) 'Corporate Social Responsibility and Corporate Governance', Economic Affairs, Social Science Electronic Publishing, Inc, (29)4, pp. 5-10.

Sweeney, L. (2009) 'A Study of Current Practice of Corporate Social Responsibility (CSR) and an Examination of the Relationship between CSR and Financial Performance Using Structural 
Equation Modelling (SEM)', Doctoral Thesis (Unpublished), Dublin Institute of Technology, Dublin.

Tausif M. (2012) 'Corporate Social Responsibility Practices: An Exploratory Study', ABHINAV, National Monthly Refereed Journal Of Research in Commerce \& Management, Vol.1 (5), May, pp. 36-41.

Tehrani, R., Salehi, M., Valipour, H. and Lashky, M. J. (2009) 'The Survey of the political Costs and Firm Size: Case from Iran’, Business Intelligence Journal, Vol. 2(2):319-342.

Tombs, S. (2005) 'Regulating Safety at Work. Policy and Practice', Health and Safety, 3(1): 516

Tounés, A., Chakroun, W. and Gribaa, F. (2011) 'A Spatio-Temporal Odyssey Around the Concepts of Sustainable Development and Corporate Social Responsibility: Boundaries to Be Determined? Journal of Modern Accounting and Auditing, October, 7(10): 1158-1168.

Ufadhili, M. K., Yambayamba, K. and Fox, T. (2005) 'How can Corporate Social Responsibility Deliver in Africa? Insights from Kenya and Zambia', Perspectives on Corporate Responsibility for Environment and Development, IIED, Number 3, July: 1-5.

UNESCO-UNEVOC (2012) 'Transforming TVET from idea to action' UNESCO-UNEVOC International Centre for Technical and Vocational Education and Training, UN Campus, Bonn, Germany.

United Nations Development Organisation (2009) 'Boosting the private sector as an engine of growth and poverty reduction', Newsletter 3, November Edition, p.1.

Valmohammadi, C. (2011) 'Investigating corporate social responsibility practices in Iranian organizations: An ISO 26000 perspective’ Business Strategy Series, 12(5):257 - 263.

van Tulder, R. and van der Zwart, A. (2006) 'International Business-Society Management’, New York: Routledge.

Visser, W. (2008) 'Corporate Social Responsibility in Developing Countries', in A. Crane, A. McWilliams, D. Matten, J. Moon \& D. Siegel (eds.), The Oxford Handbook of Corporate Social Responsibility, Oxford: Oxford University Press, 473-479.

Vrajlal K. S. and Kandarp V. P. (2010) 'Corporate Governance \& Public Governance’, Lambert Academy Publishing GmbH \& Co. KG.

Waddock, S. A., and Graves, S. B. (1997) 'The corporate social performance-financial performance link', Strategic Management Journal, 18: 303-319.

Walsh, J. P., Weber, K., and Margolis, J. D. (2003) 'Social issues and management: Our lost cause found', Journal of Management, 29: 859-881.

Watts, Ross. L. and Zimmerman, J. L (1990) 'Positive Accounting Theory: A Ten Year Perspective’, The Accounting Review, Vol. 65(1):131-156

Watts. R.L. and Zimmerman. J.L., (1978) 'Towards a Positive Theory of the Determination of Accounting Standards”, The Accounting Review, Vol. 53, No 1, pp. 112-134. 
WesternZagros Annual Report (2012) 'Corporate Social Responsibility', Available: http://www.westernzagros.com/wp-content/uploads/2013/05/Western_Zagros_2012-

AR.pdf/(Accessed: 6 March, 2014).

Wood, D. (1991) 'Corporate Social Performance Revisited', The Academy of Management Review. 16(4), pp. 691-718.

World Bank (2003) 'Better Governance for Development in the Middle East and North Africa: Enhancing Inclusiveness and Accountability', World Bank Washington, D.C. Available: http://go.worldbank.org/LGTT1USV00 (Accessed: 26 February, 2014).

Yekini, K. and Jallow, K. (2012) 'Corporate community involvement disclosures in annual report: A measure of corporate community development or a signal of CSR observance?' Sustainability Accounting, Management and Policy Journal, Vol. 3(1):7 - 32.

Young, T. (1999) 'The State and Politics in Africa', Journal of Southern African Studies, Vol. 25(1), pp. 149-154.

Zain (2013) 'Zain Bahrain and the Community. Social/CSR Report', Available: http://www.bh.zain.com/ZainPortal/ZainBahrain_CSR.jsp (Accessed: 6 March, 2014).

\section{Note:}

\section{About the authors}

Ismail Adelopo is an Associate Professor in Accounting and Finance, University of the West of England. His research interests cover corporate social responsibility and governance. He is a chartered certified accountant with a doctorate in Accounting and Finance.

Kemi Yekini is a Senior Lecturer in Accounting and Finance, De Montfort University, Leicester UK. She is an Associate Chartered Accountant and a Certified Fraud Examiner - (CFE). Her research interests include corporate disclosure practices, CSR communication, corporate governance and Fraud examination.

Lukman Raimi holds BSc (Hons) in Economics, Obafemi Awolowo University, Nigeria; MSc in Economics, University of Lagos; MSc in Industrial Relations \& Personnel Management, University of Lagos and presently PhD Finalist in Entrepreneurship \& CSR at De Montfort University. His teaching and research interests include: Entrepreneurship, Development Economics, Corporate Governance and Corporate Social Responsibility. 